University of Florida Levin College of Law

UF Law Scholarship Repository

UF Law Faculty Publications

Faculty Scholarship

Summer 2011

\title{
Comprehensive Seagrass Restoration Planning in Southwest \\ Florida: Science, Law and Management
}

\author{
Althea S. Hotaling \\ R. Benjamin Lingle \\ Thomas T. Ankersen \\ University of Florida Levin College of Law, ankersen@law.ufl.edu
}

Follow this and additional works at: https://scholarship.law.ufl.edu/facultypub

Part of the Environmental Law Commons, and the Water Law Commons

\section{Recommended Citation}

Althea S. Hotaling, R. Benjamin Lingle \& Thomas T. Ankersen, Comprehensive Seagrass Restoration Planning in Southwest Florida: Science, Law and Management, 4 Sea Grant L. \& Pol'y J. 61 (2011), available at http://scholarship.law.ufl.edu/facultypub/690 


\title{
Comprehensive Seagrass Restoration Planning in Southwest Florida: Science, Law and Management
}

\author{
Althea S. Hotaling, ${ }^{1}$ R. Benjamin Lingle, ${ }^{2}$ and Thomas T. Ankersen ${ }^{3}$
}

Abstract: In coastal Florida, the development and maintenance of docks, marinas, and channels frequently cause destruction of seagrass beds. Seagrass loss is accompanied by a loss of the ecosystem services the beds provide, such as sediment stabilization, water filtration, protection from storms, and habitat and nursery grounds for fish species. The current legal framework for seagrass protection and the implementation of mitigation for seagrass loss could be improved. In this Article, the authors argue that policymakers could revise the Uniform Mitigation Assessment Method to include more assessments related specifically to the ecology of seagrass beds and their ecosystem services. Seagrass mitigation is currently carried out by the permittee that applied to create or maintain the seagrass-impacting development. In comparison, wetland mitigation is typically carried out by publicly or privately operated mitigation banks. The creation of mitigation banks for seagrass restoration would streamline the process of seagrass mitigation and promote the public's interest in seagrass restoration.

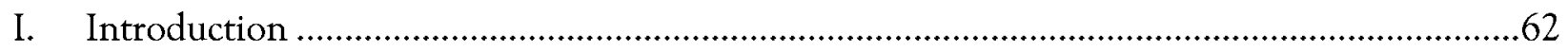

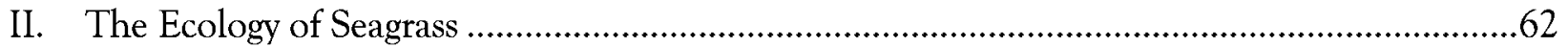

A. Historic Seagrass Coverage and Trends ......................................................................64

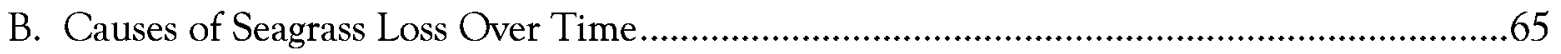

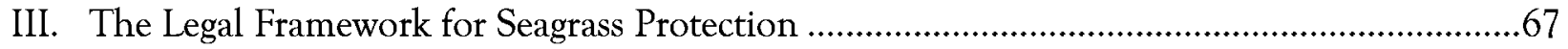

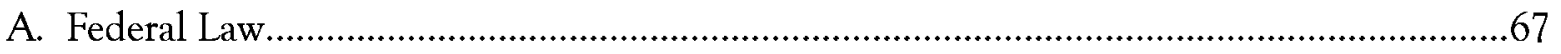

1. The River and Harbors Appropriations Act of 1899 ..................................................67

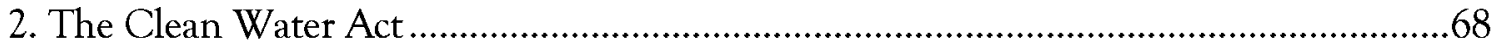

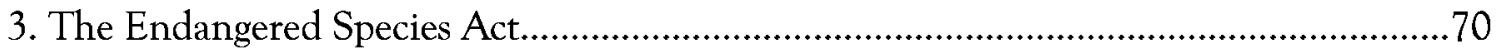

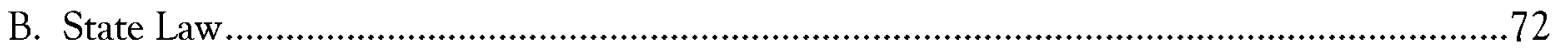

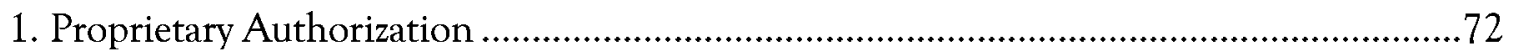

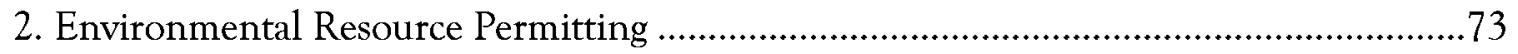

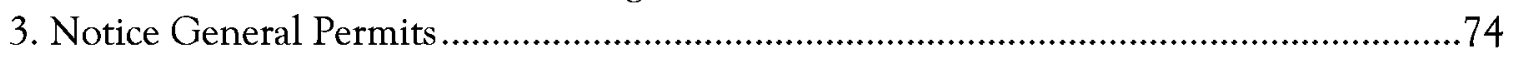

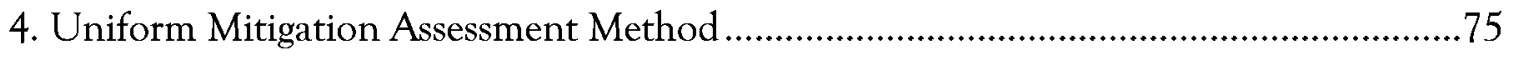

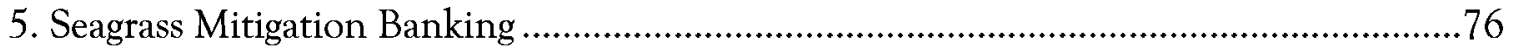

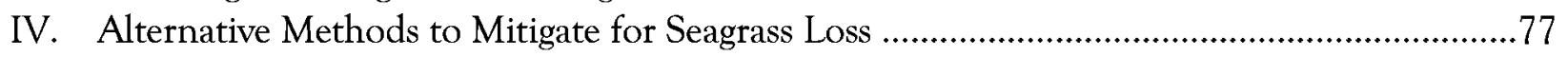

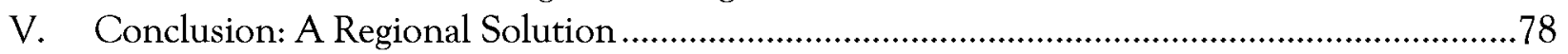

${ }^{1}$ Ph.D Student, University of Florida School of Natural Resources and Environment, 2013. Thank you Professor Ankersen, and all those who spoke to us about the issues covered in the Article. Their advice and feedback made this Article possible.

${ }^{2}$ J.D., University of Florida Levin College of Law, 2011. Thank you to Professor Thomas Ankersen and all those who helped make this Article possible.

${ }^{3}$ J.D., University of Florida College of Law, 1986. Director, University of Florida Conservation Clinic. 


\section{Introduction}

Population growth is occurring worldwide, and a substantial percentage of the growth is in coastal areas. Southwest Florida is no exception. Along with increasing population comes development to serve the growing community. Development inevitably results in the loss of natural habitats. In coastal areas, the development and maintenance of docks, marinas, and channels frequently causes the destruction of seagrass beds. Seagrass loss means a loss of the ecosystem services seagrasses provide coastal communities, including services such as sediment stabilization, water filtration, protection from storms, and habitat and nursery grounds for fish species.

Seagrasses inhabit the sovereign submerged lands Florida holds in trust for the state's citizens. Through the public trust doctrine, the state protects the public's interest in both using these areas for boating, fishing, and swimming and in protecting the natural resources that make boating, fishing, and swimming enjoyable. Conflict arises from the fact that while development and navigation are often in the public interest, so is the protection of natural resources. To resolve this conflict, current policy allows for development on sovereign submerged lands but requires mitigation to compensate the public for any ecosystem services that are lost.

This Article makes the case that the current method of determining and implementing mitigation for seagrass loss could be improved. Policymakers could revise the Uniform Mitigation Assessment Method to include more assessments related specifically to the ecology of seagrass beds and their ecosystem services. Seagrass mitigation is currently carried out by the permittee that applied to create or maintain the seagrass-impacting development. In comparison, wetland mitigation is typically carried out by mitigation banks. The creation of mitigation banks for seagrass restoration would streamline the process of seagrass mitigation and promote the public's interest in seagrass restoration.

Part II of this Article describes the ecology of seagrass, while Part III describes the historic and current extent of seagrass coverage in southwest Florida. Part IV covers the array of factors that lead to the damage and loss of seagrass in coastal areas. Part V provides an overview of the federal and state laws and regulations that apply to seagrass protection and restoration efforts. Part VI describes alternative methods of seagrass mitigation that coastal authorities in southwest Florida are implementing. Part VII concludes with a plan for improving seagrass restoration.

\section{The Ecology of Seagrass}

Seagrasses are aquatic angiosperms that inhabit marine environments. ${ }^{4}$ They grow in underwater meadows in sheltered coastal waters and are typically characterized by long, narrow green leaves, which make them superficially look like terrestrial grasses, hence the name seagrass. While seagrasses complete their entire lifecycle underwater, they must grow in water shallow enough for photosynthesis to take place. ${ }^{5}$ This typically limits them to average water depths of two meters or less. There are about sixty species of seagrasses in the world. ${ }^{6}$ The primary species present

\footnotetext{
${ }^{4}$ C. Den Hartog \& John Kuo, Taxonomy and Biogeography of Seagrasses, in SEAGRASSES: Biology, ECOLOGY AND CONSERVATION 1 (A. W. D. Larkeum et al. eds., 2006). Angiosperms are flowering plants.

${ }^{5}$ Id. at 2.

${ }^{6}$ Robert J. Orth et al., A Global Crisis for Seagrass Ecosystems, 56 BIOSCI. 987, 987 (2006).
} 
in southwest Florida are turtle-grass (Thalassia testudinum), shoal-grass (Halodule wrightii), and manatee-grass (Syringodium filiforme).

Seagrasses have a number of ecological roles. They are a food source for grazers such as endangered West Indian manatees (Trichechus manatus) and green sea turtles (Chelonian mydas). Organisms like sponges, bivalves, and barnacles live permanently in seagrass and help filter and clean water by actively trapping organic matter from the water column. ${ }^{7}$ Further, the structure of seagrass leaves and the canopy created when all the leaves combine can modify the velocity of waves and water current, helping to remove sediment and to improve water quality in estuarine systems. ${ }^{8}$ This enhances sedimentation of suspended particles and prevents sediment resuspension, thus slowing erosion. ${ }^{9}$ Sediment stabilization is also facilitated by the dense network of rhizomes and roots associated with seagrasses. ${ }^{10}$ These rhizomes and roots also protect coastlines from storms by dissipating wave energy. ${ }^{11}$

Seagrass beds are important habitat for commercially and recreationally significant species. ${ }^{12}$ Many of the small fish found in seagrass are non-commercial species; however, they are an important food source for commercial species. Although very few species depend on seagrass yearround or throughout their entire lives, many species depend on seagrass during a critical time of the year or during a particular stage in their lifecycle. ${ }^{13}$ The structural complexity of seagrass beds provides protection from predators for small or juvenile fish. Seagrasses further provide an increase in available food, improving survival and growth for juvenile organisms.

Seagrasses are linked to other marine and even terrestrial ecosystems by the movement and foraging of predators and herbivores and by the passive movement of seagrass biomass and algae caused by water flow. ${ }^{14}$ This allows seagrasses to play an integral role in coastal nutrient cycling. Seagrasses export nutrients through leaf loss/decay and through consumption by foragers; seagrasses import nutrients through nitrogen fixation and nutrient uptake. ${ }^{15}$ There is plenty of biomass to move around, as seagrasses have extremely high productivity. Research shows seagrasses annually produce an average of 1,012 grams of dry weight per square meter. ${ }^{16}$ When compared to the annual production of other communities that occur in similar ecosystems, such as macroalgae's annual production of 365 grams of dry weight per square meter and phytoplankton's annual

\footnotetext{
${ }^{7}$ Nuria Marba et al., Seagrass Beds and Coastal Biogeochemistry, in SEAGrasses: BIOLOGY, ECOLOGY AND CONSERVATION 136 (A. W. D. Larkeum et al. eds., 2006).

${ }^{8}$ Mark S. Fonseca, Brian E. Julius \& W. Judson Kenworthy, Integrating Biology and Economics in Seagrass Restoration: How Much is Enough and Why?, 15 ECOLOGICAL ENG'G 227, 232 (2000).

${ }^{9}$ Marba, supra note 7.

${ }^{10}$ Edmund P. Green \& Frederick T. SHORT, World Atlas of SeAgrasses 1 (2003).

${ }^{11} I d$.

${ }^{12}$ Michael W. Beck et al., The Identification, Conservation, and Management of Estuarine and Marine Nurseries for Fish and Invertebrates, 51 BIOSCI. 633, 633 (2001).

${ }^{13}$ Bronwyn M. Gillanders, Seagrasses, Fish, and Fisheries, in SEAGRASsES: BIOlOGy, ECOLOGY AND CONSERVATION 503 (A. W. D. Larkeum et al. eds., 2006).

${ }^{14}$ Kenneth L. Heck Jr. et al., Trophic Transfers from Seagrass Meadows Subsidize Diverse Marine and Terrestrial Consumers, 11 ECOSYSTEMS 1198, 1198 (2008).

${ }^{15}$ M. A. Hemminga, P. G. Harrison, \& F. van Lent, The Balance of Nutrient Losses and Gains in Seagrass Meadows, 71 MAR. ECOL. ProG. SER. 85, 85 (1991).

${ }^{16}$ Carlos M. Duarte \& Carina L. Chiscano, Seagrass Biomass and Production: A Reassessment, 65 AQUATIC BOTANY 159, 159 (1999).
} 
production of 128 grams of dry weight per square meter, seagrass is three to eight times as productive. ${ }^{17}$ The high primary productivity of seagrasses means that they play a large role in oceanic carbon fixing, contributing approximately $15 \%$ to the ocean's global carbon sequestration. $^{18}$

Seagrasses provide so many ecosystem services that it is difficult to put a price tag on their worth. A 1997 study found that for nutrient cycling alone seagrass was valued at $\$ 19,004$ a hectare per year. ${ }^{19}$ A study in 2006 estimated the value of seagrass in Florida's Indian River Lagoon to be $\$ 30,888$ a hectare per year. ${ }^{20}$ In the years since these studies, the value of each hectare of seagrass has only gone up. Depending on the severity of the degradation and the location and accessibility of the site, the cost for restoring seagrass ranges from $\$ 250,000$ to $\$ 2,500,000$ per hectare. ${ }^{21}$

\section{A. Historic Seagrass Coverage and Trends}

It is difficult to determine how much seagrass the world contains. There are $16,400,000$ hectares of documented beds, but many beds remain undocumented. ${ }^{22}$ If one factors in the areas where seagrass may exist, there could be as many as fifty million hectares of seagrass; however, this is likely an overestimation. ${ }^{23}$ In the last two decades, the documented loss of seagrass has been approximately $3,300,000$ hectares, or $20 \%$ of the total documented seagrass coverage in the world. $^{24}$

Southwestern Florida's Charlotte Harbor National Estuary Program (CHNEP) estimates that in the 1950's there were 24,893 hectares of seagrass from Venice Beach in the north to Estero Bay and Bonita Beach in the south. ${ }^{25}$ CHNEP drew these calculations from aerials taken in the 1950's that are impossible to ground truth and are limited in terms of clarity. The 2009 CHNEP study set the target number of hectares needing restoration in southwest Florida at $1,600 .^{26}$ The study did

\footnotetext{
${ }^{17}$ Id. at 171.
}

${ }^{18}$ Id. at 172 .

${ }^{19}$ Robert Costanza et al., The Value of the World's Ecosystem Services and Natural Capital, 387 NATURE 253, 256 (1997). A hectare is ten thousand square meters. It converts to 2.47 acres.

${ }^{20}$ W. Judson Kenworthy et al., Seagrass Conservation Biology: An Interdisciplinary Science for Protection of the Seagrass Biome, in SeAgrasses: Biology, ECOlOGY ANd Conservation 599 (A. W. D. Larkeum et al. eds., 2006).

${ }^{21} I d$.

${ }^{22}$ Green \& Short, supra note 10 , at 14 .

${ }^{23}$ Id.

${ }^{24}$ Diana I. Walker, Gary A. Kendrick \& Arthur J. McComb, Decline and Recovery of Seagrass Ecosystems - The Dynamics of Change, in SEAgrasses: Biology, ECOlOGY ANd CONSERVATION 552 (A. W. D. Larkeum et al. eds., 2006).

${ }^{25}$ Anthony Janicki, Michael Dema \& Mike Wessel, Water Quality TARgET REFInEMENT Project TasK 2: SEAGRASS TARGET DEVELOPMENT 10 (2009).

${ }^{26}$ Id. at 30 . 
not try to quantify the quality of current seagrass beds. ${ }^{27}$ Some historically thick and lush beds, though currently present, may be sparse and scarred. Future studies would benefit from assessing the quality of seagrass beds in the area instead of looking only at quantity.

\section{B. Causes of Seagrass Loss Over Time}

There are a number of reasons why seagrass beds are declining worldwide. Some of the direct anthropogenic causes of seagrass loss are propeller scarring (prop scarring) and dredging. Prop scarring occurs when a boat does not have sufficient draft, which is the distance between the bottom of the boat and the seagrass bed. This results in the propeller tearing and cutting up seagrass roots, stems, and leaves, producing a long narrow furrow devoid of seagrass. Of Florida's approximate $1,100,000$ hectares of seagrass, more than 70,011 hectares are scarred. ${ }^{28}$ As the population of Florida's coastal residents and seasonal visitors continues to increase, so do the number, size, and power of vessels used in shallow, coastal environments. These increases result in extensive scarring of seagrass beds. ${ }^{29}$ Blow outs, or large circular areas from which seagrass has been removed, frequently occur when a boat runs aground.

In the past fifty years, dredging from twenty documented projects has caused a loss of 21,023 hectares of seagrass beds. ${ }^{30}$ There are many more dredging projects where seagrass damage was not quantified or reported at all. Dredging harms seagrass by physically removing it from the channel and by increasing turbidity in the area. Frequently, however, dredging is necessary to create and maintain navigation channels. ${ }^{31}$ In some cases, creating a channel through a shallow area may cause a small loss of seagrass within the channel but may provide protection for the surrounding beds by giving boats a safe way to navigate through an area, thereby decreasing potential for scarring. Further, new environmental dredging techniques minimize adverse impacts on seagrass. ${ }^{32}$ For example, turbidity plumes are reduced when hydraulic dredging increases the ratio of water to sediment that is removed from the dredging canal. ${ }^{33}$

Anthropogenic impacts also occur indirectly. Some of these impacts, like eutrophication, can be more difficult to trace and to recognize but are frequently more harmful than direct impacts. ${ }^{34}$ Developing an area often leads to changes in water quality and quantity. High nutrient loads, particularly nitrogen and phosphorus from waste and agricultural runoff, enter estuaries and lead

${ }^{27}$ The CHNEP study found that currently there are 25,132 hectares of seagrass beds in the study area, 239 more hectares than were present during the 1950's. Though about half the areas in the study appeared to have more seagrass coverage, about half appeared to have less. The 1,600 hectares targeted for restoration are in the areas with decreased seagrass coverage. Though boating patterns suggest that existing beds are likely patchier and more scarred than they were in the 1950's, the study did not address these factors.

${ }^{28}$ F.J. Sargent et al., Scarring of Florida's Seagrasses: Assessment and Management Options, in FLORIDA MARINE RESEARCH InSTITUTE TECHNICAL REPORTS TR-1 1 (Theresa M. Bert et al eds., 1995).

${ }^{29}$ Id. at 3.

${ }^{30}$ Paul L.A. Erftemeijer \& Roy R. Robin Lewis III, Environmental Impacts of Dredging on Sea Grasses: A Review, 52 MARINe POllution Bulletin 1553, 1559 (2006).

${ }^{31}$ Id. at 1553.

${ }^{32}$ Id. at 1564.

${ }^{33}$ Id.

${ }^{34}$ Eutrophication is the addition of excessive nutrients into a waterbody, thus causing excessive algal blooms. 
to higher levels of epiphytes and algae. ${ }^{35}$ Epiphytes and algae are problematic to seagrass beds because they limit the amount of sunlight that reaches seagrass blades. High epiphyte levels have been linked to low shoot densities and low seagrass biomass. ${ }^{36}$ When the volume of algae in the water column is high, less light reaches seagrasses growing on the bottom, leading to a decline in seagrass numbers. ${ }^{37}$

Development further affects seagrasses by changing the amounts of sediment, freshwater, and saltwater that enters an estuary. Sedimentation is often associated with land use changes inland of the seagrass beds. When sediment washes into an estuarine system it increases turbidity, limiting the amount of light that reaches seagrass in much the same way as excessive algae in the water column does. ${ }^{38}$ Severe sedimentation, which commonly occurs after storm events, can physically cover seagrass beds. Developments impact freshwater quantity by altering the timing and amount of freshwater that flows into bays and estuaries. Similarly, construction of bridges and canals can affect seagrass by altering the amount of saltwater entering an estuary. ${ }^{39}$

Humans further impact seagrass by removing large predatory fish for consumption, which alters the food webs of seagrass beds and leads to an abundance of small predators like pinfish. The small predators feed on epiphytic algae-grazers such as gastropods, causing their populations to crash. Low numbers of algae-grazing gastropods cause epiphytic algae to proliferate, preventing seagrass from photosynthesizing and leading to a loss in seagrass numbers. ${ }^{40}$

Another indirect anthropogenic impact on seagrass is climate change and the associated rise in sea level. There is high uncertainty surrounding how different types of ecosystems will react and adapt to climate change. Climate trends are complex and are governed by a multitude of processes. Some locales are likely to get warmer while others may actually become cooler as changes in ocean currents and winds bring warm water and air over landmasses. Average yearly global sea level rise is currently about 1.3 millimeters, plus or minus 0.7 millimeters, but is projected to increase up to 3.8 millimeters, plus or minus 1.3 millimeters, per year by $2080 .^{41}$ This is an average of 0.26 to 0.59 meters of sea level rise by 2100. Sea level rise in the Gulf of Mexico is expected to be 0.05 meters greater than the global average. Many researchers argue that sea level rise will likely exceed 1 meter by $2100 .^{42}$

${ }^{35}$ Brian E. Lapointe, David A. Tomasko \& William R. Matzie, Eutrophication and Trophic State Classification of Seagrass Communities in the Florida Keys, 54(3) BULlETIN OF MARINE SCIENCE 696, 696 (1994). Epiphytes are plants that grow on seagrass blades.

${ }^{36}$ David A. Tomasko \& Brian E. Lapointe, Productivity and Biomass of Thalassia Testudinum as Related to Water Column Nutrient Availability and Epiphyte Levels: Field Observations and Experimental Studies, 75 MAR. ECOL. PROG. SER. 9, 9 (1991).

${ }^{37}$ Lapointe, Tomasko \& Matzie, supra note 35, at 696.

${ }^{38}$ Peter J. Ralph et al., Human Impacts on Seagrasses: Eutrophication, Sedimentation, and Contamination, in SEAGRASSES: Biology, ECOlOGY AND CONSERVATION 575 (A. W. D. Larkeum et al. eds., 2006).

${ }^{39}$ Id. at 573 .

${ }^{40}$ K. L. Heck Jr. \& J. F. Valentine, The Primacy of Top-down Effects in Shallow Benthic Ecosystems, 30(3) ESTUARIES AND COASTS 371, 376 (2007).

${ }^{41}$ Gerald A. Meehl et al., Global Climate Projections, in Climate Change 2007: The Physical Science BASIS, CONTRIBUTION OF WORKING GROUP 1 TO THE FORTH ASSESSMENT REPORT OF THE InTERgovernmental PANEL On Climate Change 812 (Solomon, S., et al. eds., 2007).

${ }^{42}$ Jeremy L. Weiss, Jonathan T. Overpeck \& Ben Strauss, Implications of Recent Sea Level Rise Science for LowElevation Areas in Coastal Cities of the Conterminous U.S.A., 105 ClimatiC CHANGE 635, 635 (2011). 
Whether the sea level rises 0.5 meter or 1 meter in the next 90 years, the distribution of seagrass will shift as temperatures and water depths change. ${ }^{43}$ Seagrass in Florida appears to be mostly light-limited, and as water depths increase, deficiencies in light available for photosynthesis will lead to losses of seagrasses from the deep edge of the beds. Water clarity is also likely to decrease as scientists predict the frequency and intensity of extreme weather events to increase.

The effects of climate change on seagrass populations are not one-dimensional, however, as some elements of climate change may actually increase seagrass populations. One of the main drivers of global climate change is an increase in atmospheric $\mathrm{CO}_{2}$. An increase in atmospheric $\mathrm{CO}_{2}$ will also increase $\mathrm{CO}_{2}$ concentrations in seawater, which one study found to cause higher reproductive output, below-ground biomass, and new shoots in non light-limited seagrass beds. ${ }^{44}$ However, in light-limited seagrass beds, $\mathrm{CO}_{2}$ enrichment did not improve seagrass growth. ${ }^{45}$

The anthropogenic impacts to seagrass have been severe; however, there are ongoing efforts to protect and restore them. The remainder of this Article will look at how federal, state, and local laws and regulations protect seagrass and encourage restoration. The Article will also evaluate changes that could further support seagrass protection and restoration while minimizing negative impacts to the livelihoods of southwest Floridians.

\section{The Legal Framework for Seagrass Protection}

\section{A. Federal Law}

Those engaged in seagrass restoration must be cognizant of the various federal environmental laws governing natural resources. Seagrass restoration is likely to implicate at least three federal statutes: the Rivers and Harbors Appropriations Act of 1899 (RHA), ${ }^{46}$ the Clean Water Act (CWA), ${ }^{47}$ and the Endangered Species Act (ESA). ${ }^{48}$ All three statutes will add wrinkles to the restoration process; however, with informed decision-making, parties engaged in restoration should be able to complete their projects without running afoul of federal law.

\section{The River and Harbors Appropriations Act of 1899}

Congress enacted the RHA in an effort to maintain and regulate the navigability of the nation's waters. ${ }^{49}$ Among other things, the Act regulates the construction of bridges, dams, piers, bulkheads, and other obstructions to navigability in or over the nation's navigable waters. ${ }^{50}$ The

\footnotetext{
${ }^{43}$ Frederick T. Short \& Hilary A. Neckles, The Effects of Global Climate Change on Sea Grasses, 63 AQUATIC BOTANY 169, 169 (1999).

${ }^{44}$ Sherry L. Palacios \& Richard Zimmerman, Response of Eelgrass Zostera Marina to $\mathrm{CO}_{2}$ Enrichment: Possible Impacts of Climate Change and Potential for Remediation of Coastal Habitats, 344 MAR. ECOL. PROG. SER. 1, 1 (2007).

${ }^{45} \mathrm{Id}$.

${ }^{46} 33$ U.S.C. $\$ \$ 401-67$.

${ }^{47}$ Id. $\$ \$ 1251-1387$.

${ }^{48} 16$ U.S.C. $\$ \$ 1531-44$.

${ }^{49}$ See generally 33 U.S.C. $\$ \$ 401-67$.

${ }^{50}$ Id. $\$ \S 401,403$.
} 
Act also makes it illegal to "throw, discharge, or deposit" refuse into navigable waters. ${ }^{51}$ Of pertinence to seagrass restoration projects, the RHA regulates activities excavating or placing fill in navigable waters. ${ }^{52}$ Although 1972 's CWA also regulates much of the RHA's subject matter, ${ }^{53}$ the RHA remains both good law and a necessary component of seagrass restoration plans.

The provisions regulating the placement of fill in navigable waters are found in RHA $\S 10$, which reads,

[I]t shall not be lawful to excavate or fill, or in any manner to alter or modify the course, location, condition, or capacity of, any port, roadstead, haven, harbor, canal, lake, harbor of refuge, or enclosure within the limits of any breakwater, or of the channel of any navigable water of the United States, unless the work has been recommended by the Chief of Engineers and authorized by the Secretary of War prior to beginning the same. ${ }^{54}$

This section is applicable to seagrass restoration projects because both seagrass and the soil that is deposited along with seagrass are considered fill. ${ }^{55}$

The U.S. Army Corps of Engineers (Corps) implements this legislation. The Corps expounds upon its regulation of fill in navigable waters in Part 323 of the Code of Federal Regulations (Code). ${ }^{56}$ Within this Part, the Corps defines fill as, "material placed in waters of the United States where the material has the effect of: (i) [r] eplacing any portion of a water of the United States with dry land; or (ii) [c]hanging the bottom elevation of any portion of a water of the United States." ${ }^{57}$ The provisions continue by providing examples of fill, including things such as "rock, sand, soil, clay, plastics, construction debris, wood chips, overburden from mining or other excavation activities, and materials used to create any structure or infrastructure in the waters of the United States." 58 The Corps further elaborates on its navigable waters regulatory authority in Parts 320 through 332 of the Code. ${ }^{59}$

\section{The Clean Water Act}

Congress preserved the Corps' authority in regulating fill in navigable waters with the enactment of the Federal Water Pollution Control Act Amendments of $1972{ }^{60}$ Known popularly as the CWA, this legislation memorialized the $92^{\text {nd }}$ Congress' aspirations to "restore and maintain the chemical, physical, and biological integrity of the Nation's waters." ${ }^{61}$ Seagrass restoration

${ }^{51} I d . \S 407$.

${ }^{52}$ Id. $\$ 403$.

${ }^{53}$ Id. $\$ \$ 1251-1387$.

${ }^{54} I d$. $\S 403$. Though codified as $\S 403$, this section is popularly referenced by its public law designation, $\S$ 10 .

5533 C.F.R. \$ 323.2(e).

${ }^{56} \mathrm{Id}$.

${ }^{57}$ Id. $\$ 323.2(\mathrm{e})(1)(\mathrm{i})$-(ii).

${ }^{58}$ Id. $\$ 323.2(\mathrm{e})(2)$.

${ }^{59}$ Id. $\$ \$ 320-332$.

${ }^{60} 33$ U.S.C $\$ \S 1251-1387$. See specifically $\$ 1344$, regulating dredge and fill activities in navigable waters and maintaining permitting authority with the Corps.

${ }^{61}$ Id. $\$ 1251$. 
projects implicate the CWA because $\$ 404$ regulates dredge and fill activities in navigable waters. ${ }^{62}$ Section 404 reads, "[t]he Secretary may issue permits, after notice and opportunity for public hearings for the discharge of dredged or fill material into the navigable waters at specified disposal sites." ${ }^{63}$ Based on the same definition of fill discussed in reference to the RHA, ${ }^{64}$ the Corps' $\S 404$ permitting authority extends to seagrass restoration projects conducted in the nation's navigable waters.

Though falling within $\S 404$ jurisdiction, certain seagrass restoration projects may be exempt from the individual permitting process if the project falls within one of the Corps' nationwide permits. Nationwide permits are Corps-issued permits authorizing a category of activities that only minimally impact navigable waters. ${ }^{65}$ To be eligible for a nationwide permit, the activity impacting navigable waters must be conducted in accordance with the conditions dictated in the permit. ${ }^{66}$

Permits 18 and 13 could potentially apply to seagrass restoration projects. Nationwide Permit 18 authorizes "[m]inor discharges of dredged or fill material." ${ }^{67}$ This is limited to discharges of less than twenty-five cubic yards of fill within no more than $1 / 10$ of an acre of water. ${ }^{68}$ Though potentially applicable, these limitations would preclude all but very small restoration projects from utilizing this permit.

Permit 13 authorizes bank stabilization to combat shoreline erosion. ${ }^{69}$ This permit would be limited to seagrass restoration projects conducted as part of a Living Shoreline project. ${ }^{70}$ To utilize the permit, however, the project must meet a number of limiting criteria. ${ }^{71}$ For example, the project must impact less than 500 feet of shoreline, must involve less than a cubic yard of fill per linear foot, and must not be in a "special aquatic area," 72 which the Code defines as "geographic areas, large or small, possessing special ecological characteristics of productivity, habitat, wildlife protection, or other important and easily disrupted ecological values." ${ }^{73}$

${ }^{62} \mathrm{Id} . \S 1344$.

${ }^{63}$ Id. $\$ 1344(\mathrm{a})$.

${ }^{64} 33$ C.F.R. $\$ 323.2(\mathrm{e})$.

${ }^{65}$ For information on the Corps' Nationwide Regulatory Program, see http://www.usace.army.mil/cecw/pages/nw_permits.aspx.

${ }^{66} \mathrm{Id}$.

${ }^{67}$ U.S. ARMY CORPS OF ENG'RS, DECISION DOCUMENT NATIONWIDE PERMIT 18 at 1 (2011), available at http://www.usace.army.mil/CECW/Documents/cecwo/reg/nwp/NWP_18_2007.pdf.

${ }^{68}$ Id. The Permit states that the discharge cannot "cause loss of more than $1 / 10$ acre of waters of the United States." "Loss of waters of the United States" occurs when waters are "permanently adversely affected," such as by "increase[ing] the bottom elevation of a waterbody." U.S. ARMY CORPS OF ENG'RS, 2007 NATIONwIDE PERMits, CONDITIONS, FurTher InFORMATION, AND DEFINITIONS (WITH CORRECTIONS) 35 , available at http://www.usace.army.mil/CECW/Documents/cecwo/reg/nwp/nwp2007_gen_conditions_def.pdf.

${ }^{69}$ U.S. ARMY CORPS OF ENG'RS, DECISION DOCUMENT NATIONWIDE PERMIT 13 at 1 (2011), available at http://www.usace.army.mil/CECW/Documents/cecwo/reg/nwp/NWP_13_2007.pdf.

${ }^{70} \mathrm{~A}$ Living Shoreline is a project where an eroded shoreline is protected or restored by introducing organic materials such as plants or oyster shells rather than hardened armoring.

${ }^{71}$ Nationwide Permit 13 Decision Document, supra note 69.

${ }^{72} \mathrm{Id}$.

${ }^{73} 40$ C.F.R. $\$ 230.3(q-1)$. 
Neither Permit 18 nor Permit 13 will apply to the majority of seagrass restoration projects. Therefore, most projects will require project-specific consultation with the Corps and procurement of an individual $\S 404$ permit. However, even if consultation and permitting satisfies the dictates of the RHA and the CWA, parties engaged in seagrass restoration must be aware of the requirements of the ESA and the potential consequences of violating this statute.

\section{The Endangered Species Act}

In the year following the CWA's enactment, the $93^{\text {td }}$ Congress enacted the ESA to protect endangered and threatened species from extinction. ${ }^{74}$ The legislation aimed "to provide a means whereby the ecosystems upon which endangered species and threatened species depend may be conserved, to provide a program for the conservation of such ... species, and to take such steps as may be appropriate to achieve the purposes of the [nation's] treaties and conventions." ${ }^{75}$ The Fish and Wildlife Service (FWS) implements the ESA for terrestrial, avian, and freshwater species; the National Oceanic and Atmospheric Administration (NOAA) implements the ESA for marine species. ${ }^{76}$ The ESA implicates seagrass restoration activities because seagrass serves as habitat for endangered and threatened species and because Florida is home to an endangered seagrass species.

One of the key provisions of the ESA is found in $\S 7$ of the Act. Section 7 requires all federal agencies to consult the FWS before taking action that may impact an endangered or threatened species. ${ }^{77}$ The federal agency must assure that its activities, including those it does not conduct but rather funds or authorizes, are "not likely to jeopardize the continued existence of any endangered species or threatened species or result in the destruction or adverse modification of [critical] habitat." ${ }^{18}$ The ESA discusses critical habitat in $\$ 4$, dictating that the governing agency will use "the best scientific data available" and will consider economic impacts, national security, and other relevant factors when designating critical habitat. ${ }^{79}$ However, the governing agency must list an area as critical habitat if "failure to designate such area as critical habitat will result in the extinction of the species concerned."

In addition to $\$ 7$, the second crucial element of the ESA is $\S 9$, which prohibits any "take" of an endangered or threatened animal. ${ }^{81}$ Section 9 does not apply to threatened or endangered plants. A "take" is any action that will "harass, harm, pursue, hunt, shoot, wound, kill, trap, capture, or collect" a protected species. ${ }^{82}$ Section 9 is not limited to direct harm of protected animals, but extends to actions that adversely implicate a protected animal's critical habitat. ${ }^{83}$

${ }^{74} 16$ U.S.C. $\$ 1531$ et. seq.

${ }^{75} \mathrm{Id}$. $\$ 1531(\mathrm{~b})$.

${ }^{76}$ See James Salzman \& Barton H. Thompson, JR., Environmental Law and Policy 258 (2003). The National Marine Fisheries Service is the division within NOAA that is charged with implementing NOAA's ESA responsibilities.

7716 U.S.C. $\$ 1536(\mathrm{a})(2)$.

${ }^{78} \mathrm{Id}$. Subsection (h) of $\S 7$ provides criteria to be considered in granting an exemption to $\S 7$ 's ban on adverse impacts to endangered and threatened species and habitat. See id. $\$ 1536(\mathrm{~h})$.

${ }^{79}$ Id. \$ 1533(b)(2).

${ }^{80} I d$.

${ }^{81}$ Id. $\$ 1538$.

${ }^{82} I d . \$ 1532(19)$. It also includes an "attempt to engage in any such conduct." Id.

${ }^{83}$ See Salzman \& Thompson, Jr., supra note 76, at 265-66. 
Pursuant to federal rule, "[h]arm in the definition of 'take' ... means an act which actually kills or injures wildlife. Such act may include significant habitat modification or degradation where it actually kills or injures wildlife by significantly impairing essential behavioral patterns, including breeding, feeding or sheltering." ${ }^{84}$ This rule, promulgated by the FWS in 1981, has been a source of considerable controversy. ${ }^{85}$ By regulating habitat modification, the rule implicates any number of activities solely because an activity is conducted in an area critical to a protected species.

In September of 1998, NOAA listed Johnson's Seagrass (Halophila johnsonii) as a threatened species. ${ }^{86}$ Found in the intertidal zone and coastal lagoons of southeast Florida from Biscayne Bay to Sebastian Inlet, Johnson's Seagrass exhibits flowers, spatulate leaves in pairs, and longnecked fruits. ${ }^{87}$ The species is distinguished from most other seagrasses by its asexual reproduction and by its distinct leaves. ${ }^{88}$

Johnson's Seagrass' asexual reproduction limits its ability to expand its distribution; however, its endangerment is further exacerbated by the anthropomorphic interferences discussed in Part IV of this Article. ${ }^{89}$ A prime obstacle to Johnson's Seagrass' well-being is prop scarring. ${ }^{90}$ Scarring destroys root systems, cuts through the plant's subterranean plant stems, and diminishes the stability of the substrate. ${ }^{91}$ Dredging poses similar obstacles. ${ }^{92}$ In addition to these direct perturbations, sedimentation and degraded water quality caused by human activities pose further problems for Johnson's Seagrass. ${ }^{93}$

Federal efforts to protect the species began in 1993 when NOAA issued a Notice of Proposed Rulemaking to list Johnson's Seagrass as a threatened species. Two years after NOAA's 1998 final listing, the agency designated Johnson's Seagrass' critical habitat in southeast Florida. In 2002, the agency published the Johnson Seagrass' recovery plan. $^{94}$

So long as it is listed as a protected species, Johnson's Seagrass will remain a necessary consideration when planning and implementing a seagrass restoration project in southeast Florida. Though exempt from the "take" prohibition of $\$ 9$, other provisions within the section may still apply to restoration projects. Those commencing projects on federal land may not "remove and reduce to possession" nor "maliciously damage or destroy" any protected plants such as Johnson's Seagrass. ${ }^{95}$ Section 9 also dictates that one may not "deliver, receive, carry, transport, ... ship[,] ... sell[,] or offer for sale" any threatened or endangered plant. ${ }^{96}$ Further, ESA $\S 7$ will put burdens on

84 50 C.F.R. $\$ 17.3(\mathrm{c})(3)$.

${ }^{85}$ See Salzman \& Thompson, Jr., supra note 76, at 266.

86 U.S. Fish and Wildlife Service, Species Profile, Johnson's Seagrass (Halophila johnsonii), http://ecos.fws.gov/speciesProfile/profile/speciesProfile.action?spcode=Q3AL.

87 NOAA Fisheries, Office of Protected Resources, Johnson's Seagrass (Halophila johnsonii), http://www.nmfs.noaa.gov/pr/species/plants/johnsonsseagrass.htm.

${ }^{88} \mathrm{Id}$.

${ }^{89} \mathrm{Id}$.

${ }^{90} \mathrm{Id}$.

${ }^{91}$ Id.

${ }_{92}$ Id.

${ }^{93} \mathrm{Id}$.

${ }^{94} \mathrm{Id}$.

${ }^{95} 16$ U.S.C. $\$ 1538(\mathrm{a})(2)(\mathrm{B})$.

${ }^{96}$ Id. $\$ 1538(\mathrm{a})(2)(\mathrm{C})-(\mathrm{D})$. 
any project involving federal licensure or funding. ${ }^{97}$ Because many projects will require a CWA $\S$ 404 permit, those interested in seagrass restoration in Johnson's Seagrass habitat will be compelled to consider the ESA and to avoid adverse impacts to the threatened species.

In addition to inquiring whether the seagrass bed involved in restoration is a protected species, those engaged in restoration must also consider whether the seagrass bed is critical habitat to an endangered or threatened species. Seagrass beds in Florida provide habitat and food for many animals, including the endangered West Indian manatee (Trichechus manatus), first listed as endangered under an ESA precursor in $1967 . .^{98}$ The West Indian manatee, a large marine mammal indigenous to Florida and the Caribbean, travels between salt and fresh water environments. ${ }^{99}$ Manatees are herbivores; they consume both marine and freshwater plants, including many species of seagrass. ${ }^{100}$ Those engaged in seagrass restoration should be aware of whether their activities are within manatee's critical habitat and of any restrictions or limitations the designation will impose on the proposed restoration project.

\section{B. State Law}

In addition to satisfying the dictates of the RHA, the CWA, and the ESA, those interested in pursuing seagrass restoration must also obtain the requisite state permits and authorizations. There are at least two components to securing Florida's approval for a seagrass restoration project: proprietary authorization to use Florida's sovereign submerged lands ${ }^{101}$ and an Environmental Resource Permit to engage in activities in surface waters or wetlands. ${ }^{102}$

\section{Proprietary Authorization}

Sovereign submerged lands are those lands below the mean high water line on tidally influenced navigable waters ${ }^{103}$ and those lands below the ordinary high water line on non-tidally influenced navigable waters. ${ }^{104}$ Sovereign submerged lands do not include those lands that were formerly sovereign but that have been alienated by the state. ${ }^{105}$ Though alienation of sovereign lands was fairly routine for many decades, it is no longer a common practice. Sovereign submerged

\footnotetext{
${ }^{97}$ Id. $\$ 1536(\mathrm{a})(2)$.

${ }^{98}$ See U.S. Fish and Wildlife Service, Species Profile, West Indian Manatee (Trichechus manatus), http://ecos.fws.gov/speciesProfile/profile/speciesProfile.action?spcode=A007.

${ }^{99}$ Fact Sheet, U.S. Fish and Wildlife Service, West Indian Manatee (Trichechus manatus) (2008), available at http://www.fws.gov/endangered/esa-library/pdf/manatee.pdf.

${ }^{100}$ See FWS, supra note 98.

${ }^{101}$ FLA. STAT. $\$ 253.77(1)$.

${ }^{102}$ Id. $\$ 373.414$.

${ }^{103}$ See FLA. CONST. art. X $\S 11$ ("Sovereignty lands.-The title to lands under navigable waters, within the boundaries of the state, which have not been alienated, including beaches below mean high water lines, is held by the state, by virtue of its sovereignty, in trust for all the people. Sale of such lands may be authorized by law, but only when in the public interest. Private use of portions of such lands may be authorized by law, but only when not contrary to the public interest.").

${ }^{104}$ Florida Supreme Court precedent establishes the importance of the ordinary high water mark and how it is to be established. See generally Tilden v. Smith, 13 So. 708 (Fla. 1927).

${ }^{105} \mathrm{Id}$.
} 
lands are held in trust for the people of Florida by the Board of Trustees of the Internal Improvement Trust Fund. ${ }^{106}$ Pursuant to Florida Statutes $\$ 253.77(1)$, “A person may not commence any excavation, construction, or other activity involving the use of sovereign or other lands of the state ... until the person has received the required lease, license, easement, or other form of consent authorizing the proposed use." ${ }^{107}$

The rules governing such authorization are codified in Chapters $18-20$ and 18-21 of the Florida Administrative Code. Chapter 18-21 outlines the general guidelines; Chapter 18-20 outlines the more stringent guidelines for the submerged lands found in one of Florida's Aquatic Preserves. Both sets of guidelines dictate that authorization will be given on a case-by-case basis. Chapter 18 21 states, "[a]ctivities on sovereignty lands shall be designed to minimize or eliminate adverse impacts on fish and wildlife habitat, and other natural or cultural resources. Special attention and consideration shall be given to endangered and threatened species habitat." ${ }^{108}$ Seagrass restoration projects fit within these parameters and should be viewed favorably by permitting staff. The rules on Aquatic Preserves specifically touch on restoration, listing "[r]estoration/enhancement of altered habitat or natural functions, such as ... re-establishment of shoreline or submerged vegetation" as an example of a specific benefit to be considered when analyzing whether a project is in the public interest. ${ }^{109}$ Though the process may be time-consuming, properly planned seagrass restoration projects should merit approval and be given proprietary authorization to proceed on sovereign lands.

\section{Environmental Resource Permitting}

In addition to proprietary authorization, those interested in seagrass restoration must also obtain the requisite permits to engage in activities that impact the state's wetlands or surface waters. Florida Statutes Chapter 373 Part IV describes the process of obtaining a permit before engaging in such activities. To acquire a permit, there must be "reasonable assurance" that the proposed activity will not degrade water quality standards and will not contravene the public interest. ${ }^{110}$ In determining whether the activity is consistent with the public interest, the governing authority will look at a number of factors:

1. Whether the activity will adversely affect the public health, safety, or welfare or the property of others;

2. Whether the activity will adversely affect the conservation of fish and wildlife, including endangered or threatened species, or their habitats;

3. Whether the activity will adversely affect navigation or the flow of water or cause harmful erosion or shoaling;

4. Whether the activity will adversely affect the fishing or recreational values or marine productivity in the vicinity of the activity;

5. Whether the activity will be of a temporary or permanent nature;

\footnotetext{
${ }^{106}$ See FlA. CONST. art. X \$ 11; FLA. STAT. \$ 253.02-03.

${ }^{107}$ FLA. STAT. $\$ 253.77(1)$.

${ }^{108}$ FLA. ADMIN. CODE ANN. r. 18-21(2)(i).

${ }^{109}$ Id. r. $18-20.004(2)(d)(4)$

${ }^{110}$ FLA. STAT. $\$ 373.414$.
} 
6. Whether the activity will adversely affect or will enhance significant historical and archaeological resources ...; and

7. The current condition and relative value of functions being performed by areas affected by the proposed activity. ${ }^{111}$

Permits are issued through a program implemented jointly by Florida's DEP and the state's regional water management districts. ${ }^{112}$ In weighing the requisite factors, the governing agency will assess the activity's direct, secondary, and cumulative impacts to the state's waters. ${ }^{113}$ In addition to the authority to issue individual permits, the permitting authority may exempt by statute or rule activities that would have only minor impacts to the state's waters and may grant "noticed general permits" for larger but similarly benign projects. ${ }^{14}$

\section{Notice General Permits}

Chapter $62-341$ of the Florida Administrative Code outlines the noticed general permit regulatory scheme and codifies the various noticed general permits the state has adopted. ${ }^{115}$ Such permits are for "those activities that have been determined to have minimal impacts to the water resources of the District, both individually and cumulatively, when conducted in compliance with the terms and conditions of the general permit."116

Noticed general permits for dredging frequently require permittees to minimize adverse impacts to sovereign submerged lands and to mitigate damages to natural seagrass communities. ${ }^{117}$ Permits have included requirements to keep detailed information on the dredged material disposal site, to provide a natural resource inventory of the dredging area, and to give information on dredging done in the area within the past five years. ${ }^{118}$ Permits have further required water quality monitoring and relocation of seagrasses, corals, sponges, and oysters within the dredge footprint. ${ }^{119}$ In adherence to duties under the ESA, state permitting authorities have mandated observers to be on site to look for manatees whenever dredging takes place and to stop dredging if a manatee

${ }^{111}$ Id. $\$ 373.414(1)(\mathrm{a})(1)-(7)$.

112 See Fla. Dep't of EnVt'l Prot., OVERView of the Wetland and Other Surface Water REgulatory AND PROPRIETARY PROGRAMS IN FlORIDA 2 (Feb. 23, 2011), http://www.dep.state.fl.us/water/wetlands/docs/erp/overview.pdf.

${ }^{113}$ Id. at 7 ("Secondary impacts are those actions or actions that are very closely related and directly linked to the activity under review that may affect wetlands and other surface waters and that would not occur but for the proposed activity ... Cumulative impacts are residual adverse impacts to wetlands and other surface waters in the same drainage basin that have or are likely to result from similar activities (to that under review) that have been built in the past, that are under current review, or that can reasonably be expected to be located in the same drainage basin as the activity under review.")

${ }^{114}$ Id. at 4.

115 FLA. ADMIN. CODE r. 62.341.

${ }^{116}$ Id. r. 62.341.201(1).

${ }^{117}$ Id. r. 341.494(2)(c)-(d).

${ }^{118}$ Id. r. 341.494(3)(a)(3), r. 62-341.494(3)(a)(6), r. 62-341.494(3)(a)(7).

${ }^{119}$ Id. r. 341.494(3)(a)(9), r. 62-341.494(3)(a)(10)(c). 
comes within fifty feet of dredging equipment. ${ }^{120}$ These requirements all relate to minimizing impacts to seagrass communities and to animals in the dredge area.

\section{Uniform Mitigation Assessment Method}

If there is a loss of natural seagrass communities, permits also frequently mandate mitigation. The extent of mitigation required for a particular project is determined by application of the Uniform Mitigation Assessment Method (UMAM). Mandated by Florida Statutes $\$ 373.414(18)$ and promulgated through Florida Administrative Code Rule 62-345, UMAM is Florida's exclusive process for establishing the acreage of mitigation needed to offset adverse impacts to the state's wetlands and surface waters and to award and deduct mitigation bank credits. ${ }^{121}$ UMAM provides a practical, consistent, and scientifically sound process that takes into account the varied ecological communities found throughout the state. ${ }^{122}$ In determining appropriate mitigation, UMAM considers the impacted water's current condition, location, use by wildlife, hydrologic condition, and uniqueness. ${ }^{123}$

As promulgated, UMAM is most easily applied to wetland mitigation assessments and must be interpreted for use on seagrass mitigation. UMAM uses three categories of indicators to determine wetland function and assess a wetland score: location and landscape support, water environment, and community structure. ${ }^{124}$ For each category, the wetland indicators are judged as optimal, moderate, minimal, or not present. ${ }^{125}$ Because of their distinct ecology, seagrass beds inherently have many of the wetland indicators and functions that may be absent in terrestrial wetlands.

For example, wetlands may occur in an upland matrix, but seagrasses only occur in an aquatic matrix of mixing salt and freshwater. Their location in an aquatic matrix as opposed to an upland matrix means that virtually all seagrass beds will be connected to other habitats. This results in seagrass beds consistently receiving high scores for the location category.

For water environments, there is only one assessment point specific to seagrass: "water depth, wave energy, currents, and light penetration are optimal for the type of community being evaluated." Wetlands are typically evaluated on eleven characteristics to determine the quality of the water environment, thus giving regulators more criteria to work with when evaluating proper mitigation levels. Under community structure, there is again only one assessment for evaluation of

\footnotetext{
${ }^{120}$ Id. r. $62-341.494(3)(\mathrm{a})(10)(\mathrm{g})(8)$.

${ }^{121}$ See Uniform Mitigation Assessment Method, FlA. ADMIN. CODE r. 62-345.100(1). See also FLA. STAT. \& 373.414(18). For more information on UMAM, see ClARK HULL ET AL., CHAPTER 62-345: FlORIDA'S UNIFORM MITIGATION ASSESSMENT METHOD 2, http://www.dep.state.fl.us/water/wetlands/docs/mitigation/umam_basics.pdf.

${ }^{122}$ Clark Hull, et al., Chapter 62-345: Florida's Uniform Mitigation Assessment Method 3, http://www.dep.state.fl.us/water/wetlands/docs/mitigation/umam_basics.pdf.

${ }^{123}$ See Fla. Admin. CODE r. 62-345.300(2). See also Clark Hull ET Al., CHAPTER 62-345: FloridA's UNIFORM MITIGATION ASSESSMENT METHOD 4, http://www.dep.state.fl.us/water/wetlands/docs/mitigation/umam_basics.pdf.

${ }^{124}$ FLA. ADMIN. CODE r. 62-345.500(6).

${ }^{125}$ Id. r. 62-345.500(5).

${ }^{126}$ Id. r. $62-345.500(6)(\mathrm{b})(1)(\mathrm{l})$.
} 
submerged aquatic communities such as seagrass: to receive a high score there simply has to be no evidence of siltation or algal growth. ${ }^{127}$

If permitting authorities are to continue using UMAM to determine seagrass mitigation, the rule should be updated to include more information specific to the ecology of seagrass beds. For location and landscape, it is important to know whether the seagrass is located near or within other beds, whether there are impediments to the movement of wildlife and water, and the nature of upland land uses (e.g., the percentage of the land that is impermeable and whether there are structures such as docks, marinas, and water treatment facilities). When looking at the water environment, it is necessary to know if the tidal cycle, climate, available light, water depth, turbidity, water quality, and erosion levels are appropriate for seagrass. To determine if a seagrass community is healthy, one must measure the amount of epiphytic growth and siltation and one must determine the density, distribution, canopy presence, and regeneration of the seagrass bed. Including these criteria in UMAM would allow those engaged in seagrass restoration to better assess the functions of existing beds.

\section{Seagrass Mitigation Banking}

In addition to the limitations caused by using UMAM's wetland-focused criteria when assessing seagrass mitigation needs, a further hurdle to effective seagrass restoration is caused by the state's lack of seagrass mitigation banks. In 2008, the Florida Legislature enacted a bill to amend Florida Statutes Chapter 253 to allow for the establishment of seagrass mitigation banks on sovereign submerged lands. ${ }^{128} \mathrm{CS} / \mathrm{HB} 7059$ added an eighteenth subsection to Florida Statutes $\S$ 253.03, reading:

The Board of Trustees of the Internal Improvement Trust Fund may ensure the preservation and regeneration of seagrass, as defined in s. 253.04(4)(a)2., by providing for the establishment of seagrass mitigation banks, pursuant to s. 373.4136 , to offset the unavoidable impacts of projects where such banks meet the applicable public interest test of chapters 253 and 258 . This subsection shall not prohibit mitigation for impacts to seagrass or other habitats on sovereignty submerged lands for other types of projects, or for projects occurring on nonsovereign submerged lands, upon applicable approval of the board of trustees. ${ }^{129}$

Two months after its enactment, however, Governor Charlie Crist vetoed the bill. ${ }^{130}$ Though citing concern that seagrass mitigation banks could streamline projects that negatively impact

${ }^{127}$ Id. r. $62-345.500(6)(\mathrm{c})(1)(\mathrm{a})(\mathrm{IX})$.

${ }^{128}$ For information on the history of the bill, as well as the bill's text, see FLORIDA HOUSE OF REPRESENTATIVES CS/HB 7059 - FISH AND WILDLIFE (2008), http://www.myfloridahouse.gov/sections/Bills/billsdetail.aspx?BillId=39493.

${ }^{129}$ FLA. CS/HB 7059 (2008), available at

http://www.myfloridahouse.gov/Sections/Documents/loaddoc.aspx?FileName=_h7059er.xml\&Document Type $=$ Bill\& BillNumber $=7059 \&$ Session $=2008$.

130 See Florida HOUSE OF RePresentatives CS/HB 7059 - Fish AND Wildlife (2008), http://www.myfloridahouse.gov/sections/Bills/billsdetail.aspx?BillId=39493. 
seagrass beds, ${ }^{131}$ Governor Crist's veto effectively served to eliminate a potential tool for seagrass restoration. UMAM is designed to award and to deduct mitigation bank credits for activities affecting the state's wetlands and surface waters; however, the lack of seagrass mitigation credits makes this goal difficult to effectuate for seagrass restoration projects. Consequently, parties required to mitigate for their impacts to seagrass beds must engage in a tedious process of searching for alternative mitigation for each surface water-impacting activity that results in the loss of seagrass beds.

\section{Alternative Methods to Mitigate for Seagrass Loss}

Despite the lack of seagrass mitigation credits, permitting authorities have tools available to permit seagrass mitigation efforts. One mitigation option used in southwest Florida is the establishment of No Internal Combustion Motor Zones (NICMZ). ${ }^{132}$ NICMZs permit only the use of electric motors and prohibit the use of internal combustion motors in designated areas. ${ }^{133}$ Along with the establishment of these zones, the permittee is required to monitor seagrasses in the area to document change in coverage and number of prop scars. ${ }^{134}$ In other areas of Florida, authorities have required permittees to fund the building of runoff treatment plants or install non-regulatory signs to inform boaters of shallow water seagrass beds. ${ }^{135}$

Non-regulatory signs have proven successful in deterring boaters from entering sensitive seagrass areas. In 2007, the Sebastian Inlet District constructed a channel that impacted 1.25 hectares of seagrass habitat. ${ }^{136}$ Several mitigation projects were completed to offset the impacts. One project required the permittee to place informational signs reading, "Caution, Shallow Water, Seagrass Area" around the inlet's seagrass beds. The signs clearly delineate forty-five hectares of seagrass beds. If boaters follow the recommendations, forty-five hectares will be protected from boating impacts. ${ }^{137} \mathrm{~W}$ ithin three years of regulators installing the signs, the area experienced the regeneration of one hectare of seagrass, for a current total of forty-six acres of protected area. ${ }^{138}$

The Sebastian Inlet District also conducts an annual inventory of anthropogenic damage within the newly protected areas. Before the District erected signage in 2007, there were 506 verified scars in the beds; by 2009 , the number of verified scars dropped to $188 .{ }^{139}$ This number remained stable into 2010 , with only 189 verified scars. ${ }^{140}$ One particular area of the beds showed an increase in scarring from 2007 to 2010; all other areas showed a decrease. This may point to a need to improve signage at this particular location. The overall reduction in scarring from 2007 to 2010 indicates that boaters heed the advice of the signage and use the channel.

131 Crist Kills Seagrass Bill Enviros Didn't Like, ORLANDO SENTINEL (JUNE 30, 2008), http://blogs.orlandosentinel.com/news_politics/2008/06/crist-kills-sea.html.

${ }^{132}$ FLA. ADMIN. CODE r. 62-341.494(2)(d).

${ }^{133} \mathrm{Id}$.

${ }^{134}$ Id. r. $62-341.49(2)(\mathrm{d})(3)$.

135 PbS\&J, Sebastian Inlet Channel, Comprehensive Seagrass mitigation Program, year 3 MONITORING REPORT, prepared for Sebastian Inlet District, 1 (2011).

${ }^{136} \mathrm{Id}$.

${ }^{137}$ Id.

${ }^{138}$ Id. Current estimates are for 2010.

${ }^{139}$ Id. at 28.

${ }^{140} \mathrm{Id}$. 
Governing authorities implemented a similar project in Tampa Bay in 1992. Two different types of signs were installed in this project. Some areas were signed non-combustion engine zones (an essential equivalent to the NICMZs mentioned above) while others were simply signed, "Caution Shallow Water Seagrass Area." ${ }^{141}$ Data shows no difference in the number of new scars between the two areas. ${ }^{142}$ Due in part to lobbying pressures from boating advocates, current state regulations make the installation of exclusion zone signage more difficult to effectuate than the installation of non-regulatory signage. As the two zones in the Tampa Bay project were equally effective in protecting seagrass, the governing authorities recommended that exclusion zones be changed to caution zones. This would achieve the same result of seagrass protection without relying on the disfavored regulatory signage.

\section{Conclusion: A Regional Solution}

There is no doubt that seagrass beds provide invaluable ecosystem services. As coastal populations continue to grow, there will continue to be anthropogenic effects on seagrass beds; therefore, it is essential that law and policy facilitate seagrass restoration. At a regional level, areas in need of restoration should be identified and prioritized using good science. The most urgent needs should be addressed first rather than addressing needs through a piecemeal, uncoordinated effort. ${ }^{143}$ Areas slated for restoration could become part of a mitigation bank used to fund further restoration. Mitigation banks should be located in each region so that local impacts result in local mitigation. This is not always the case with terrestrial wetland mitigation. Further, policymakers should consider amending UMAM to include seagrass-specific ecosystem services. This will enable permitting authorities to assess seagrass systems' worth and to appropriately mitigate for their losses. Amending state policy in these regards could facilitate efforts to restore the state's seagrass beds while reasonably accommodating the inevitable activities that will continue to impact the state's sovereign submerged lands.

\footnotetext{
${ }^{141}$ Jacob F. Stowers, Eric Fehrmann \& Andrew Squires, Seagrass Scarring in Tampa Bay: Impact Analysis and Management Options, in SEAGRASS MANAGEMENT: IT'S NOT JUST NUTRIENTS 48 (H.S. Greening, ed., 2000). ${ }^{142} I d$.

${ }^{143}$ There continue to be growing efforts to facilitate ecological planning at the regional level. One recent initiative is NOAA's Coastal and Marine Spatial Planning Program (CMSP Program). See National Oceanic and Atmospheric Association, Coastal and Marine Spatial Planning, NOAA's CMSP Programing, http://cmsp.noaa.gov/program/index.html. The CMSP Program is a federal, state, and tribal initiative that will provide technical and monetary assistance to regional ecological management. The Program will provide "[1] Observation and monitoring programs, [2] Geospatial referencing, web mapping, and spatial analysis tools, [3] Navigation charts and ocean mapping data, [4] Ecosystem mapping and characterization, [5] Data management, distribution, analysis, and archiving, [6] Weather and climate prediction, [7] Ecological modeling and forecasting, land] [8] Social and economic science-based assessments." Id. The CMSP Program may prove a valuable resource for advocates of seagrass restoration.
} 